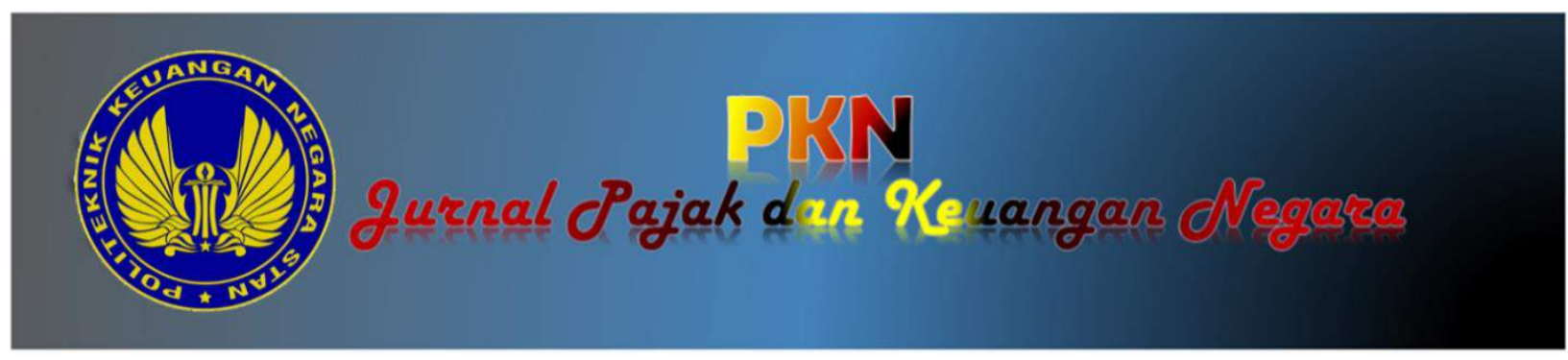

\title{
Menarik Investasi Ke Indonesia Dengan Tax Holiday
}

\author{
Irwan Aribowo \\ PKN STAN-FIA Universitas Brawijaya \\ Deny Irawan \\ PKN STAN- Direktorat Jenderal Pajak
}

Alamat Korespondensi: irwan_aribowo@pknstan.ac.id

\section{INFORMASI ARTIKEL}

Diterima Pertama

[15 Januari 2021]

Dinyatakan Diterima

[31 Maret 2021]

KATA KUNCl:

Tax Holiday, Investasi, Pajak, Signalling Theory.

KLASIFIKASI JEL:

\begin{abstract}
This research contains about how tax holiday as one of the tax incentives used by the Indonesian government to attract investment Ease of Doing Business index (EoDB) released by the World Bank. Tax holiday is expected to be able to provide a positive signal to investors that Indonesia is the right country to invest in. In this paper it was found that tax holidays are not capable of attracting investment alone, but other factors are needed in order for tax holidays to be successful in attracting investment.
\end{abstract}

\section{ABSTRAK}

Penelitian ini berisi tentang bagaimana tax holiday sebagai salah satu insentif pajak yang digunakan oleh pemerintah Indonesia untuk menarik investasi Karena pajak merupakan salah satu yang menjadi perhitungan dalam indeks kemudahan bisnis yang dirilis oleh Bank Dunia. Tax holiday diharapkan mampu memberikan sinyal positif kepada para investor bahwa Indonesia adalah negara yang tepat untuk berinvestasi. Dalam penelitian ini dtemukan bahwa tax holiday tak mampu sendirian menarik investasi, akan tetapi dibutuhkan faktor-faktor lain agar tax holiday berhasil menarik investasi, 


\section{PENDAHULUAN}

\subsection{Latar Belakang}

Efek dari krisis dunia yang terjadi sekitar tahun 2007 menjadikan perekonomian dunia saat ini masih belum stabil. Pertumbuhan Grotwh Domestic Bruto (GDP) saat ini dikatakan stagnan pada angka sekitar dua sampai tiga persen. Untuk negara-negara berkembang seperti Indonesia hal ini tentu saja bukanlah hal yang menggembirakan karena akan berdampak bagi perekonomiannya.

Untuk menjaga pertumbuhan ekonomi, negaranegara di dunia termasuk Indonesia berlomba-lomba untuk menarik investasi/penanaman modal. Banyak hal dilakukan untuk menarik investasi. Salah satunya dengan memberikan insentif pajak terhadap perusahaan yang ingin berinvestasi.

Berdasarkan indeks kemudahan berbisnis atau Ease of Doing Business index (EoDB) yang dirilis oleh Bank Dunia pembayaran pajak (paying tax) menjadi salah satu dari sepuluh pokok masalah yang menjadi penilaian dalam pemeringkatan EODB. Indeks pembayaran pajak dinilai dari empat sektor utama, yaitu prosedur pembayaran pajak, waktu untuk memenuhi kewajiban pajak, persentase beban pajak terhadap keuntungan perusahaan, dan indeks setelah pelaporan. Insentif pajak akan mengurangi beban pajak perusahaan karena adanya pengurangan/pemotongan tarif sehingga persentase beban pajak terhadap profit perusahaan menjadi lebih kecil.

Oleh karena itu melalui Peraturan Pemerintah Nomor 1 Tahun 2007 tentang Fasilitas Pajak Penghasilan untuk Penanaman Modal di Bidang-bidang Usaha Tertentu dan/atau Daerah tertentu. Pemerintah Indonesia mulai mendengungkan insentif pajak bagi para investor. Insentif pajak sendiri baru diterapkan pada tahun 2011 dengan adanya Peraturan Menteri Keuangan Nomor 130/PMK.011/2011 tentang Pemberian Fasilitas Pembebasan atau Pengurangan Pajak Penghasilan Badan. Salah satu insentif pajak yang diberikan adalah tax holiday (pembebasan pajak). Tax holiday dalam Undang-undang Nomor 25 Tahun 2007 tentang Penanaman Modal adalah pemberian pengurangan pajak penghasilan bersih sampai tingkat tertentu terhadap jumlah penanaman modal yang dilakukan dalam waktu tertentu. Pembebasan atau pengurangan pajak penghasilan badan dalam jumlah dan waktu tertentu hanya dapat diberikan kepada penanaman modal baru yang merupakan industri pionir, yaitu industri yang memiliki keterkaitan yang luas, memberi nilai tambah dan eksternalitas yang tinggi, memperkenalkan teknologi baru, serta memiliki nilai strategis bagi perekonomian nasional.

Tax holiday ini diharapkan mampu menarik investasi masuk ke Indonesia. Akan tetapi menurut penelitian yang dilakukan Howell $\mathrm{H}$. Zee, et al (2002) bahwa di negara-negara berkembang insentif pajak akan efektif apabila insentif pajak yang diterapkan telah sesuai dengan kaidah internasional. Dewi (2012) dalam tesisnya juga mengungkapkan bahwa lingkungan investasi lebih berpengaruh dalam menarik investasi daripada insentif pajak. Hal senada juga diungkapkan oleh Putri (2017) bahwa pengambilan keputusan investasi lebih dipengaruhi oleh faktorfaktor lain seperti kemudahan perizinan, besarnya pasar domestik, akses pasar internasional, infrastruktur, kondisi sosial dan keamanan, dan ketersediaan sumber daya manusia. Hubungan antara tax holiday dan investasi tidak begitu kuat.

Oleh karena itu, peneliti tertarik untuk mengetahui sejauh mana tax holiday mampu menarik investasi masuk ke Indonesia.

\section{LANDASAN TEORI}

\subsection{Signalling Theory}

Signalling Theory dikembangkan pertama kali oleh Michael Spence (1973). Teori ini menitikberatkan pada informasi yang diberikan oleh perusahaan untuk menarik investasi. Informasi ini penting bagi investor dan pelaku bisnis mengenai gambaran untuk kelangsungan hidup investasinya. Menurut Jogiyanto (2000) informasi yang dipublikasikan sebagai suatu pengumuman akan memberikan sinyal bagi investor dalam pengambilan keputusan investasi. Jika pengumuman tersebut mengandung nilai positif, maka diharapkan pasar akan bereaksi pada waktu pengumuman tersebut diterima oleh pasar.

Dalam hal ini peneliti menggunakan signalling theory untuk mengaitkan kebijakan sebagai sebuah sinyal yang diberikan oleh negara kepada para investor. Hal ini sejalan dengan yang diungkapkan oleh Bond dan Larry (1986) mengatakan bahwa perusahaan tidak mengetahui mengenai potensi dan produktivitas dari sebuah negara. Oleh karena itu, tax holiday (insentif pajak) berperan sebagai sinyal membedakan diri untuk negara-negara dengan produktivitas tinggi.

Rugman (1981) yang dikutip oleh Pramono (2006) dalam "Perkembangan Arus Investasi Ditinjau dari Perspektif Hukum Bisnis" dikatakan bahwa Penanaman Modal Asing (PMA) dipengaruhi oleh variabel lingkungan dan variabel internal. Tiga jenis variabel lingkungan yang menjadi perhatian, yakni ekonomi, non ekonomi, dan pemerintah. Variabel ekonomi terdiri atas tenaga kerja, modal, teknologi, sumber daya alam, dan keterampilan manajemen. Variabel non ekonomi meliputi variabel politik, sosial dan budaya masyarakat. Hal tersebut dikarenakan setiap negara mempunyai faktor spesifik negara yang khas yang berbeda dengan yang lainnya. Faktor lainnya adalah pemerintah yang menjadi perhatian untuk perusahaan PMA. Terdapat keragaman terkait campur tangan pemerintah dalam bisnis internasional. Kebijakan yang dilakukan pemerintah akan memberikan sebuah sinyal kepada investor mengenai keadaan negara tersebut. Sinyal yang positif seperti kebijakan-kebijakan yang akan mendukung investasi seperti pemotongan birokrasi, pengurangan tarif pajak, dan peningkatan infrastruktur akan 
memberikan dampak positif yang menarik investor untuk berinvestasi.

Berdasarkan teori-teori diatas dapat diketahui bahwa tax holiday adalah sebuah sinyal untuk investor bahwa pemerintah mendukung investasi dengan memberikan keringanan pajak.

\subsection{Insentif Pajak}

Insentif pajak menurut Suandy (2003) adalah fasilitas perpajakan yang diberikan kepada investor luar negeri untuk kegiatan tertentu atau untuk wilayah tertentu. Thuronyi (1998) berpendapat buruknya iklim investasi dari suatu negara yang antara lain dicerminkan dari kurangnya infrastruktur, ketidakpastian hukum dan rumitnya birokrasi yang menimbulkan perlunya insentif pajak.

Berdasarkan definisi di atas insentif pajak dapat diartikan sebagai suatu fasilitas yang diberikan kepada suatu perusahaan karena melakukan investasi pada sektor tertentu atau wilayah tertentu dan memenuhi syarat-syarat yang telah ditentukan.

Menurut Thuronyi (1998) jenis insentif pajak terbagi sebagai berikut.

a. Tax holiday merupakan insentif pajak yang diberikan melalui pembebasan dari pajak penghasilan badan dan/atau pengurangan tarif pajak atas pajak penghasilan badan. Tax holiday diberikan kepada perusahaan yang baru didirikan dan dengan jangka waktu yang terbatas. Jangka waktu efektif dari tax holiday tergantung dari awal berlakunya tax holiday. Awal berlakunya tax holiday dapat berupa tanggal didirikan atau terdaftarnya perusahaan secara resmi, tanggal pertama kali berproduksi atau usaha mulai dijalankan, tahun saat pertama kali mendapatkan profit, atau tahun saat pertama kali memperoleh penghasilan kena pajak.

b. Tax sparing credit merupakan suatu kredit pajak semu yang disepakati oleh negara asal investor. Tax sparing credit diperlukan agar tax holiday dapat efektif. negara asal investor memperbolehkan investor mengakui adanya kredit pajak di luar negeri dalam penghitungan pajak global walaupun dalam kenyataannya tidak ada pajak yang dibayar di negara sumber.

c. Investment Allowances and Tax Credits, tax allowance merupakan insentif pajak dengan mengurangi penghasilan kena pajak perusahaan, sedangkan tax credit langsung mengurangi jumlah pajak yang harus dibayar. Investment allowances and tax credits biasanya diberikan untuk investasi baru dengan nilai investasi tertentu.

d. Accelerated Depreciation (Timing Difference) Pemberian insentif berupa penyusutan yang dipercepat. Penyusutan dibebankan dalam periode waktu yang lebih pendek dari umur ekonomis aset tersebut atau melalui pembebanan khusus di periode tahun pertama. $\mathrm{Hal}$ ini agar perusahaan memperoleh pengembalian modalnya lebih cepat. Insentif ini hanya menggeser beban pajak ke belakang, namun tidak mempengaruhi pajak secara keseluruhan.

e. Tax Rate Reductions merupakan pengurangan tarif pajak atas penghasilan dari sumber tertentu atau kepada perusahaan yang memenuhi kriteria tertentu, seperti pengurangan tarif untuk perusahaan yang go public. Pada insentif ini pajak penghasilan tidak dibebaskan semuanya, dapat diperluas kegiatan yang sudah ada, dan tidak dibatasi jangka waktu tertentu.

\section{METODE PENELITIAN}

Penelitian ini bertujuan untuk mengukur bagaimana tax holiday mampu mempengaruhi investor untuk berinvestasi. Untuk mengukur hal tersebut peneliti melakukannya dengan cara wawancara kepada para stakeholder serta mempelajari dan mengumpulkan berbagai literatur terkait tax holiday. Berdasarkan hal tersebut jenis penelitian yang dipilih adalah metode kualitatif.

Menurut Rukajat (2018) pendekatan kualitatif adalah jenis penelitian yang temuan-temuannya tidak diperoleh melalui prosedur kuantifikasi, perhitungan statistik, atau bentuk cara lainnya yang menggunakan pengukuran angka.

Prosedur pengolahan data menggunakan model Miles, Huberman dan Saldana (2014).

Gambar 3.1 Komponen-komponen Ananlisis Data Model Interaktif

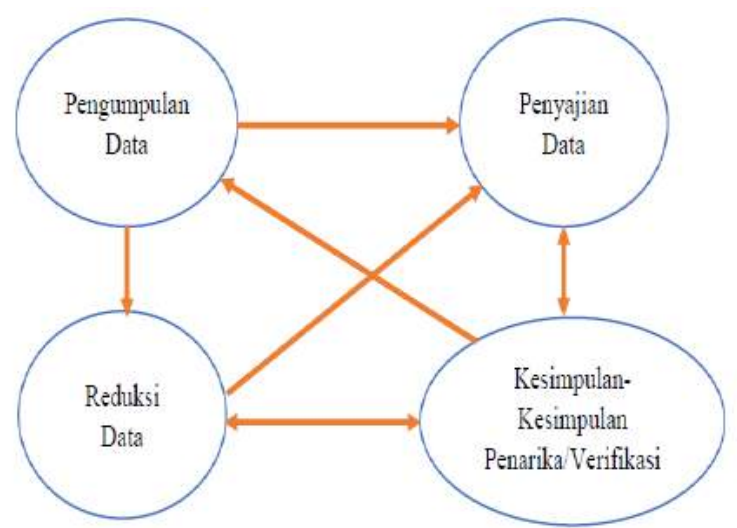

Edition 3.

Pengumpulan Data

Data yang diperoleh dari hasil studi pustaka dan wawancara dicatat dalam catatan lapangan yang terdiri dari dua bagian, yaitu catatan deskriptif dan catatan reflektif. Catatan deskriptif adalah catatan alami tanpa adanya penafsiran dan pendapat dari peneliti dari fenomena yang dilihat, dialami, dan disaksikan oleh peneliti. Untuk catatan reflektif adalah catatan yang berisi komentar, kesan, tafsiran, serta ulasan dari temuan yang dijumpai peneliti.

b. Reduksi Data

Reduksi data merupakan proses pemilihan, pemfokusan, penyederhanaan, abstraksi, dan transformasi data yang diperoleh dari lapangan. Langkah-langkah tersebut dilakukan untuk 
mempertajam analisis data. Setelah hasil wawancara dibuat catatan deskriptif dilakukan penggolongan berdasarkan pertanyaan wawancara yang kemudian direduksi yang tidak sesuai permasalahan dan terakhir dikelompokkan sesuai permasalahan penelitian.

\section{c. Penyajian Data}

Penyajian data yang telah melalui proses reduksi yang disajikan dalam suatu bentuk kumpulan informasi yang tersusun. Penyajian ini dalam bentuk teks atau dalam bentuk bagan, matriks, jaringan kerja dan sebagainya. Dalam penelitian ini penyajian dilakukan dengan bentuk tabel pada Microsoft Excel dalam setiap kelompok reduksi data.

d. Penarikan kesimpulan

Setelah direduksi dan disajikan, peneliti menarik simpulan yang mampu memberi jawaban atas masalah penelitian yang telah dirumuskan sebelumnya. Dalam penarikan simpulan peneliti juga melihat keseluruhan data dari data awal sampai yang telah direduksi untuk meyakini kesimpulan yang didapat sudah tepat.

\subsection{Sumber Data}

Sumber data penelitian didapatkan melalui dokumentasi berbagai dokumen seperti buku, jurnal, peraturan, artikel, dan literatur lainnya terkait tentang tax holiday. Sumber data lainnya diperoleh dari informan melalui proses wawancara dengan narasumber yang terlibat dalam kebijakan tax holiday. Narasumber yang dipilih adalah orang-orang yang berhubungan dalam program tax holiday dilihat dari tiga sudut pandang yaitu, pembuat dan pelaksana kebijakan, pihak independen/asosiasi, dan akademisi.

\section{HASIL PENELITIAN}

Berdasarkan data yang didapat oleh peneliti terdapat tiga periode tax holiday yang ada di Indonesia selama tahun 2011 sampai dengan 2020. Gambar 4.1 menunjukkan pertumbuhan investasi di Indonesia sejak 2011 sampai dengan 2020. Dalam Gambar 4.1 dapat dilihat pertumbuhan investasi Indonesia trennya mengalami kenaikan. Apabila dilihat pertumbuhan investasi untuk PMA mengalami kenaikan yang cukup besar pada 2013 dan untuk PMDN pada tahun 2019. Namun hal tersebut tidak dapat disimpulkan bahwa tax holiday sukses menarik investasi. Oleh karena itu peneliti akan menguraikan bagaimana dampak setiap periode tax holiday terhadap pertumbuhan investasi dari tahun 2011 sampai dengan 2020.

Periode pertama tax holiday, yaitu pada tahun 2011 sampai dengan 2015. Berdasarkan data yang didapat tax holiday pada periode ini kurang diminati oleh investor. Hal ini terbukti dengan hanya lima wajib pajak yang mengikuti tax holiday selama tahun 2011 sampai dengan 2015. Hal yang menyebabkan tax holiday kurang diminati pada periode ini disebabkan terdapat faktor-faktor lain yang lebih dominan dalam mempengaruhi investor dalam berinvestasi dan belum dilakukan perbaikan. Hal ini seperti yang diungkapkan oleh Putri (2017) bahwa pengambilan keputusan investasi lebih dipengaruhi oleh faktor-faktor lain seperti kemudahan perizinan, besarnya pasar domestik, akses pasar internasional, infrastruktur, kondisi sosial dan keamanan, dan ketersediaan sumber daya manusia. Selanjutnya Dewi (2012) dalam tesisnya juga mengungkapkan bahwa lingkungan investasi lebih berpengaruh dalam menarik investasi dari pada insentif pajak.

Untuk menarik investasi diperlukan perbaikan faktor lainnya karena tax holiday bukan merupakan faktor utama seseorang berinvestasi. Dalam wawancara dengan salah satu pengurus nasional Asosiasi Pengusaha Indonesia (APINDO) ditemukan bahwa pengusaha tidak melihat tax holiday sebagai faktor utama, banyak sekali faktor yang diperhatikan sebelum melihat insentif pajak, seperti masalah perizinan, kepastian hukum dan situasi politik. Hal ini beberapa kali ditekankan oleh beliau, jika ingin bersaing menarik investasi. Karena Investor datang ke Indonesia tidak langsung melihat pajaknya, tetapi lebih kepada bagaimana birokrasinya, keamanan dan kestabilan politik.

Selain itu, pada periode pertama sosialisasi mengenai tax holiday masih belum berjalan dengan masif. Akibatnya belum banyak pengusaha yang mengetahui insentif ini. Selanjutnya aturan dalam periode masih banyak yang multitafsir yang berakibat kurangnya kepastian hukum mengenai proses tax holiday contohnya mengenai kriteria, tarif maupun lamanya tax holiday di berikan. Selanjutnya proses birokrasi pada periode ini sangat panjang dan melibatkan banyak stakeholder. Padahal proses birokrasi ini penting seperti yang dikatakan oleh van parys

Gambar 4.1 Data Pertumbuhan Investasi di Indonesia 2011 s.d. 2020

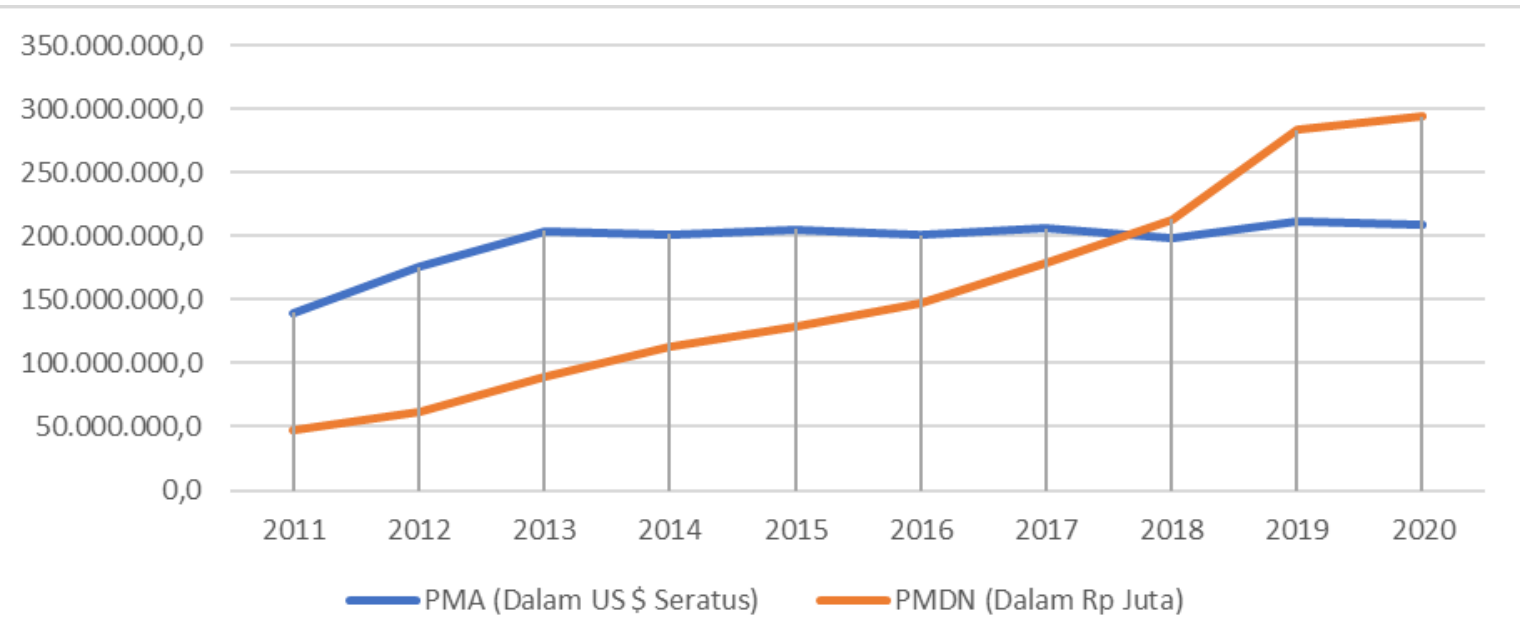


james (2009) yang dikutip dalam artikel yang ditulis yustisia (2018) bahwa Spektrum keberhasilan rezim insentif pajak berkaitan dengan tingkat kepercayaan investor. Salah satu faktor yang patut menjadi perhatian dalam membangun kepercayaan investor adalah transparansi dari sistem insentif pajak dalam rangka menjamin akuntabilitas, kepastian hukum, dan mencegah adanya korupsi. Pada peraturan yang ada saat itu belum mencakup kriteria yang jelas tentang dasar pemberian tarif dan jangka waktu pemberian fasilitas tax holiday.

Selanjutnya periode kedua tax holiday yang dimulai dengan diterbitkannya Peraturan Menteri Keuangan Nomor 159/PMK.010/2015 tentang Pemberian Fasilitas Pengurangan Pajak Penghasilan Badan dan diubah menjadi Peraturan Menteri Keuangan Nomor 103/PMK.010/2016 tentang Perubahan Atas Peraturan Menteri Keuangan Nomor 159/PMK.010/2015 tentang Pemberian Fasilitas Pengurangan Pajak Penghasilan Badan. Dengan diterbitkannya peraturan ini, maka peraturan sebelumnya resmi tidak diberlakukan lagi. Pada peraturan ini dilakukan beberapa perubahan seperti penambahan industri pionir. Meskipun cakupan industri pionir yang mendapatkan fasilitas tax holiday telah diperluas/diperbanyak. Akan tetapi, seperti tidak belajar pada periode pertama permasalahan transparansi dan kepastian hukum juga menjadi masalah dalam periode ini. Hal ini memberikan kesan pemerintah tidak serius membenahi peraturan, karena perubahan dilakukan secara setengah-setengah. Hal ini justru semakin mengurangi kepercayaan untuk mengajukan tax holiday. Akibatnya pada periode ini tidak ada wajib pajak yang menerima tax holiday.

Berdasarkan hal tersebut kegagalan tax holiday pada dua periode ini disebabkan karena desain pada dua peraturan ini sangat rumit. Setiap permohonan yang masuk harus terlebih dahulu dibahas antar kementerian terkait. Selanjutnya Komite Verifikasi akan melakukan pengujian. Prosesnya sangat panjang dan membutuhkan waktu yang tidak singkat sampai hasilnya keluar dan permohonan tax holiday tidak selalu diterima. Bahkan dalam PMK Nomor 130/PMK.011/2011 pemberian fasilitas tax holiday ini harus melalui pertimbangan Presiden.

Selanjutnya periode ketiga tax holiday yang dimulai dengan diterbitkan Peraturan Menteri Keuangan Nomor 35/PMK.010/2018 tentang Pemberian Fasilitas Pengurangan Pajak Penghasilan Badan yang menggantikan PMK Nomor 159/PMK.010/2015. Pada periode ini tax holiday mulai mengalami perubahan yang lebih baik. Baru diterbitkan tanggal 29 Maret 2018 sudah mampu menarik investor sebanyak sepuluh investor dengan total investasi sekitar 208,5 Triliun Rupiah. Padahal peraturan ini hanya berjalan selama sembilan bulan sampai dengan November 2018 dan terakhir digantikan dengan diterbitkannya Peraturan Menteri Keuangan Nomor 150/PMK.010/2018.
Pada periode ketiga ini tax holiday telah mampu mempengaruhi investasi masuk ke Indonesia. Pada periode terdapat 58 Wajib Pajak yang mengikuti tax holiday. Hal ini disebabkan beberapa perubahan dilakukan pada periode ini dan pemerintah juga melakukan perbaikan di sektor lain yang mempengaruhi investasi. Perubahan pertama adalah semakin luasnya cakupan industri yang mendapatkan fasilitas tax holiday. Pada PMK Nomor 130/PMK.011/2011 hanya lima jenis industri yang masuk ke dalam industri pionir, sedangkan di PMK Nomor 150/PMK.010/2018 menjadi delapan belas jenis industri yang masuk dalam cakupan industri pionir. Di sisi lain, dalam pasal 5 PMK 150/PMK.010/2018 juga memberikan keterbukaan dan harapan bagi industri yang tidak masuk ke dalam industri pionir yang terdapat pada pasal 2 . Industri tersebut dapat mengajukan fasilitas tax holiday, selama perusahaan tersebut memenuhi kriteria industri pionir yang terdapat pada pasal 1 .

Kedua meningkatnya kemudahan dalam proses pengajuan tax holiday. Kemudahan pertama didapatkan karena syarat minimal investasi yang makin diperkecil yang dulunya Rp1.000.000.000.000,00 (Satu triliun Rupiah) menjadi hanya Rp100.000.000.000,00 (seratus miliar rupiah) sudah dapat mengajukan tax holiday.

Ketiga dari segi birokrasi, saat ini proses tax holiday menggunakan sistem yang bernama Online Single Submission (OSS). Semua pengajuan tax holiday melalui OSS. Hal ini tentu saja memotong banyak proses birokrasi. Proses pengajuan tax holiday saat ini hanya lima hari kerja sejak dokumen lengkap. Padahal pada PMK Nomor 35/PMK.011/2011 prosesnya sangat panjang dan rumit. Prosesnya dapat bertahun-tahun sampai keputusan tax holiday keluar.

Keempat meningkatnya kepastian hukum dalam proses pengajuan tax holiday. Saat ini jelas antara nilai investasi dengan jangka waktu manfaat tax holiday. Semua lebih transparan dan jelas ukurannya. Berbeda dengan dahulu yang tidak jelas ukurannya.

Berdasarkan hal tersebut bahwa terbukti terdapat kesesuaian dengan apa yang diungkapkan dalam signalling Theory, bahwa dengan mengubah PMK terkait tax holiday pemerintah memberikan sinyal positif kepada para investor. Sinyal positif ini dapat dilihat dengan perbaikan-perbaikan yang dilakukan dengan memperbaiki yang dirasa kurang pada PMK sebelumnya. Masukan-masukan yang diberikan ditampung dan diterapkan pada PMK terbaru. Hal ini tentu memberikan sinyal pemerintah sangat memberikan kemudahan investasi di Indonesia, selain itu juga memberikan sinyal komitmen pemerintah dalam memberikan insentif pajak kepada investor. Hal ini tentu saja akan meningkatkan kepercayaan investor. Hal ini seperti yang diungkapkan oleh Parys \& James (2009) bahwa salah satu faktor keberhasilan insentif pajak berkaitan dengan tingkat kepercayaan investor. Dalam laporan Bersama IMF, OECD, UN dan WORLD BANK (2015) bahwa insentif pajak akan semakin baik 
apabila dilakukan perbaikan tata kelola seperti transparansi peraturan yang lebih baik.

\section{KESIMPULAN DAN REKOMENDASI}

\subsection{Kesimpulan}

Berdasarkan hasil pembahasan sebelumnya dapat disimpulkan bahwa tax holiday tak mampu sendirian dalam menarik investasi. Hal ini dipengaruhi oleh faktor-faktor lain seperti kemudahan perizinan, besarnya pasar domestik, akses pasar internasional, infrastruktur, kondisi sosial dan keamanan, dan ketersediaan sumber daya manusia.

Perubahan peraturan tax holiday dari tahun 2011 sampai dengan 2018 memiliki dampak positif terhadap pencapaian tujuan kebijakan tax holiday untuk menarik investasi. Terbukti jumlah wajib pajak yang mendapatkan tax holiday naik secara signifikan. Hal tersebut karena perubahan peraturan berdampak pada semakin luas cakupan industri, meningkatkan kemudahan proses pengajuan tax holiday dan meningkatkan kepastian hukum.

\subsection{Rekomendasi}

a. Perubahan yang dilakukan terkait tax holiday sangat baik. Kementerian Keuangan sebagai pembuat kebijakan harus terus mengulas peraturan tersebut karena perkembangan industri yang semakin cepat saat ini guna mengakomodir industri yang sedang berkembang dan memerlukan insentif.

b. Perlu adanya pengawasan yang ketat terhadap perusahaan yang mendapatkan SK tax holiday agar perusahaan tersebut tidak menyalahgunakan insentif yang telah diberikan.

c. Untuk meningkatkan keefektifan dari kebijakan tax holiday harus dibarengi juga dengan meningkatkan faktor lainnya yang menunjang investasi seperti infrastruktur, sumber daya manusia, stabilitas ekonomi, dan keamanan. Saat ini Indonesia masih tertinggal untuk masalah sumber daya manusia dan infrastruktur dibandingkan negara seperti Malaysia, Thailand, dan Singapura.

\subsection{Keterbatasan}

a. Terbatasnya jumlah narasumber yang didapat oleh peneliti, peneliti tidak dapat memperoleh narasumber dari perusahaan karena adanya keterbatasan akses dan kerahasiaan informasi.

b. Data yang dijadikan pembanding yang mengikuti tax holiday hanya sampai dengan awal 2020 karena pada tahun 2020 terjadi pandemi Covid-19 di seluruh dunia yang memukul ekonomi dan investasi global.

\section{DAFTAR PUSTAKA}

Anoraga Pandji. 1995. Perusahaan Multinasional dan Penanaman Modal Asing. Jakarta: Pustaka Jaya.
Azvedo, Alcino, Paulo J. Pereira, dan Artur Rodrigues. 2019. Foreign Direct Investment With Tax Holidays and Policy Uncertainty. International Journal of Finance \& Economics 24.2 Hal. 727-739.

Badan Koordinasi Penanaman Modal https://www.bkpm.go.id/en/publicati on/pressrelease (diakses 15 Februari 2021).

Blomstrom, Magnus dan Ari Kokko. 2003. The Economics of Foreign Direct Investment Incentives. NBER Working Paper No. 9489.

Bond, Eric W. dan Larry Samuelso. 1986. Tax holidays as signals. The American Economic Review, 76(4), 820-826.

Dewi, Amanda Chandra. 2012. Analisis Pemberian Insentif Pajak Berupa Fasilitas Tax Holiday di Indonesia untuk Menarik Investasi, Tesis. Depok: Fakultas Ekonomi Universitas Indonesia.

Eason, Alex. 2001. Tax Incentive for Foreign Direct Investment. Belanda : Kluwer Law International.

Jogiyanto. 2000. Teori Portofolio dan Analisis Investasi. Yogyakarta: BPFE UGM.

Miles, M.B, Huberman,A.M, dan Saldana,J. 2014. Qualitative Data Analysis, A Methods Sourcebook, Edition 3. USA: Sage Publications.

Muchammad, Zaidun. 2005. Penerapan Prinsipprinsip Hukum Internasional Penanaman Modal Asing di Indonesia (Ringkasan Disertasi) Surabaya : Program Pasca Sarjana Universitas Airlangga.

Nindyo Pramono. 2006. Perkembangan Arus Investasi Ditinjau Dan Perspektif Hukum Bisnis, Jurnal Legislasi Indonesia, Vol. 3. Jakarta: Direktorat Jenderal Peraturan Perundangundangan Departemen Hukum dan HAM RI.

Parys, Stevan Van dan Sebastian James. 2009. Why Tax Incentives mau be an ineffective tool to encouraging Investment? - The role of Investment Climate. Belgia.

Prakosa, Kesit Bambang. 2003. Analisis Pengaruh Kebijakan Tax Holiday Terhadap Perkembangan Penanaman Modal Asing Di Indonesia (Tahun 1970-1999). Jurnal Ekonomi Pembangunan Vol. 8 No. 1, Juni 2003 Hal: $19-37$.

Prasetyo, Kristian Agung. 2008. Benarkah Pemberian Insentif Pajak dapat Meningkatkan Investasi Asing di 
Indonesia. Jakarta: Inside Tax Edisi 6 Hal. 6-19.

Putri, Wika Arsanti. 2017. Insentif Pajak Dalam Membentuk Keputusan Investasi. Jakarta : AMK BSI Vol 4, No 2 Hal. 132138.

Rukajat, Ajat. 2018. Pendekatan Penelitian Kualitatif. Yogyakarta: Deepublish.

Suandy, Erly. 2003. Perencanaan Pajak Edisi Revisi. Jakarta: Salemba Empat.

Sari, Nuraini, Maya Safira Dewi, dan Yen Sun. 2015. Indonesia: The Effect of Tax Holiday on Economic Growth Related to Foreign Investment. Procedia Social and Behavioral Sciences Volume 211, 25 November 2015, Hal. 10081015.

Thuronyi, Victor. 1998. Tax Law Design and Drafting. Washington DC : IMF.

The World Bank Group. 2015. Doing Business 2015 : Going Beyond Efficiency. https://www.doingbusiness.org/conte nt/dam/doingBusiness/media/AnnualReports/English/DB15-Full-Report.pdf. (diakses 10 Januari 2021).

Yustisia, Dea. 2018. Mendorong Efektivitas Tax Holiday di Indonesia. https://news.ddtc.co.id/mendorongefektivitas-tax-holiday-di-indonesia13829 (diakses 10 Januari 2021)

Zee, Howell H., Janet G. Stotsky, dan Eduardo Ley. 2002. Tax Incentives for Business Investment: A Primer for Policy Makers in Developing Countries. World development, 30(9), 1497-1516.

Republik Indonesia. 2007. Undang-undang Republik Indonesia Nomor 25 Tahun 2007 tentang Penanaman Modal.

Republik Indonesia. 2007. Peraturan Pemerintah Republik Indonesia Nomor 1 Tahun 2007 tentang Fasilitas Pajak Penghasilan untuk Penanaman Modal di Bidang-bidang Usaha Tertentu dan/atau Daerah tertentu.

Republik Indonesia. 2015. Peraturan Pemerintah Republik Indonesia Nomor 18 Tahun 2015 tentang Fasilitas Pajak Penghasilan untuk Penanaman Modal di Bidang-bidang Usaha Tertentu dan/atau di Daerah-daerah Tertentu.

Republik Indonesia. 2016. Peraturan Pemerintah Republik Indonesia Nomor 9 Tahun 2016 tentang Perubahan Atas Peraturan Pemerintah Nomor 18 Tahun 2015 tentang Fasilitas Pajak Penghasilan untuk Penanaman Modal di Bidang-bidang Usaha Tertentu dan/atau di Daerah-daerah Tertentu.

Kementerian Keuangan 2011. Peraturan Menteri Keuangan Nomor 130/PMK.011/2011 tentang Pemberian Fasilitas Pembebasan atau Pengurangan Pajak Penghasilan Badan.

Kementerian Keuangan 2015. Peraturan Menteri Keuangan Republik Indonesia Nomor 159/PMK.010/2015 tentang Pemberian Fasilitas Pengurangan Pajak Penghasilan Badan.

Kementerian Keuangan. 2016. Peraturan Menteri Keuangan Republik Indonesia Nomor 103/PMK.010/2016 tentang Perubahan Atas Peraturan Menteri Keuangan Nomor 159/PMK.010/2015 tentang Pemberian Fasilitas Pengurangan Pajak Penghasilan Badan

Kementerian Keuangan. 2018. Peraturan Menteri Keuangan Republik Indonesia Nomor 35/PMK. 010/ 2018 tentang Pemberian Fasilitas Pengurangan Pajak Penghasilan Badan.

Kementerian Keuangan. 2018. Peraturan Menteri Keuangan Republik Indonesia Nomor 150/PMK. 010/ 2018 tentang Pemberian Fasilitas Pengurangan Pajak Penghasilan Badan. 